\title{
Lifetime risks of specific breast cancer subtypes among women in four racial/ethnic groups
}

\author{
Allison W Kurian ${ }^{1,2^{*}}$, Kari Fish ${ }^{3}$, Sarah J Shema ${ }^{3}$, Christina A Clarke ${ }^{2,3}$
}

\begin{abstract}
Introduction: Breast cancer comprises clinically distinct subtypes, but most risk statistics consider breast cancer only as a single entity. To estimate subtype-specific lifetime breast cancer risks, we took advantage of populationbased data for which information regarding tumor expression of estrogen receptor (ER), progesterone receptor (PR) and HER2/neu (HER2) was newly available.

Methods: We included women whose breast cancer was diagnosed in the state of California from 2006 to 2007 and was reported to the National Cancer Institute's Surveillance, Epidemiology and End Results Program ( $N=$ 40,936). We calculated absolute lifetime and age-specific probabilities (percent, 95\% confidence interval) of developing breast cancer subtypes defined by ER, PR, and HER2 status - luminal (ER and/or PR-positive, HER2negative), HER2-positive (ER and PR-positive or negative, HER2-positive), and triple-negative (ER-negative, PRnegative, and HER2-negative) - separately for white, black, Hispanic, and Asian women.

Results: The luminal breast cancer subtype predominates across racial/ethnic groups, with lifetime risk lowest in Hispanic women $(4.60 \%, 4.41-4.80 \%)$ and highest in white women $(8.10 \%, 7.94-8.20 \%)$. HER2-positive breast cancer varies less by race (1.56-1.91\%). Lifetime risk of triple-negative breast cancer is highest in black women (1.98\%, 1.802.17\%), compared to $0.77 \%$ (0.67-0.88\%) for Asians, $1.04 \%$ (0.96-1.13\%) for Hispanics and 1.25\% (1.20-1.30\%) for whites. Across racial/ethnic groups, nearly half of all luminal breast cancers occur after age 70.

Conclusions: These absolute risk estimates may inform health policy and resource planning across diverse populations, and can help patients and physicians weigh the probabilities of developing specific breast cancer subtypes against competing health risks.
\end{abstract}

\section{Introduction}

Breast cancers are biologically heterogeneous. Gene expression profiling of breast tumor tissues has identified reliable patterns indicative of clinically distinct subtypes [1-4]. At this time, the subtype classifications most often used in clinical settings are based on the commonly measured tumor markers estrogen receptor (ER), progesterone receptor (PR), and HER2/neu (HER2), which offer imperfect but practical surrogates for genomic profiling [5]. It is increasingly recognized that breast cancer subtypes vary in occurrence (especially by race/ ethnicity) [5-8], in their detection by screening mammography $[9,10]$, and in their risk associations with other

\footnotetext{
* Correspondence: akurian@stanford.edu

'Department of Medicine, Stanford University School of Medicine, 259

Campus Drive, Stanford, CA 94305-5405, USA Full list of author information is available at the end of the article
}

factors [11-15]. Treatment options and prognosis also depend on breast cancer subtype [9,16-18].

Despite accumulating evidence that breast cancer subtypes should be considered separately, it is still routine to present statistics that consider the disease as a single entity. Perhaps most commonly cited is the $12 \%$ lifetime probability statistic [19], prompting the widespread perception that 'one in eight' US women will develop the disease. This single estimate does not convey race-specific variation in breast cancer risks. Moreover, although some groups are reported to have greater relative risk of specific breast cancer subtypes, there are no data with which to counsel patients about the absolute magnitude of these risks in comparison with other threats to their health; one clinically important example is the ER-, PR-, and HER2-negative (triple-negative) breast cancer subtype among black women [5]. To provide estimates relevant to patient care and health policy, we took
C Biomed Central 
advantage of recent data on subtype-specific incidence patterns (collected in the large and diverse population of California) to calculate absolute lifetime risks of developing a first primary breast cancer according to breast cancer subtype and presented those calculations separately for women of four racial/ethnic groups.

\section{Materials and methods Study population}

The California Cancer Registry (CCR), a contributor to the National Cancer Institute's Surveillance, Epidemiology and End Results (SEER) program, has ascertained all cancers diagnosed in the state of California since 1988, with estimated $99 \%$ completeness. In this analysis, we included all invasive breast cancers (International Classification of Disease for Oncology, Third Edition [ICDO-3] sites 50.0 to 50.9; all histologies excluding sarcomas and lymphomas 9050 to 9055,9140 , and 9590 to 9989). The CCR has collected information on ER and PR since 1990 and on HER2 since 1999. Before the year 2006, 29\% of cases lacked HER2 data; subsequently, HER2 data completeness increased to at least $85 \%$, and thus we limited our assessment to the 40,936 women whose cancer was diagnosed between 1 January 2006 and 31 December 2007, comprising the most recent years for which data are available from the CCR. Each marker is reported as positive, negative, borderline, not tested, not recorded, or unknown. ER and PR were evaluated by dextran-coated charcoal assays or immunohistochemistry (IHC), with positive defined as greater than or equal to $5 \%$ nuclear staining; HER2 was tested by IHC (with 0 and $1+$ defined as negative, $2+$ as borderline, and $3+$ as positive) or fluorescence in situ hybridization (with fewer than or equal to two gene copies defined as negative and greater than two copies defined as positive) [20]. Tumor size and stage at diagnosis, patient age at diagnosis, race, and ethnicity were abstracted directly from the medical record; in most cases (84\%), race was derived from a patient self-report [21]. We categorized race/ethnicity as non-Hispanic (NH) white, NH black, Hispanic, and $\mathrm{NH}$ Asian or Pacific Islander (hereafter referred to as white, black, Hispanic, and Asian).

\section{Categorization of breast cancer subtypes}

We categorized breast cancer subtypes according to tumor expression of ER, PR, and HER2; we designated three subtype groupings, which are distinguished by their differences in clinical management (consisting of treatment with ER-, PR-, or HER2-targeted therapies) and by their prognosis. Similarly to previous investigators [22], we defined a 'luminal' category as ER- or PRpositive or both and HER2-negative (a category that overlaps, but does not concord completely, with the gene expression-based subtypes luminal $\mathrm{A}$ and luminal
B) $[3,4]$; other subtype categories were HER2-positive (ER- and PR-positive or -negative and HER2-positive) and triple-negative (ER-negative, PR-negative, and HER2-negative) [5-8,17].

\section{Statistical analysis}

We used DevCan software (version 6.4.1), developed by the National Cancer Institute, to compute absolute probabilities that a specific breast cancer subtype will be diagnosed and the associated 95\% confidence intervals (CIs) [23]. DevCan employs competing-risks methodology to estimate age-dependent probabilities of cancer occurrence and accounts for competing risks of death (specifically, all non-breast cancer causes of death) and is conditioned upon the patient's never having had breast cancer previously [24-27]. For each age group, DevCan calculates the probabilities of two mutually exclusive events: either developing the cancer of interest or dying from other causes without ever having developed the cancer of interest. Consequently, cause-specific mortality data are required to estimate incidence of the cancer of interest. The DevCan program uses data on cause-specific mortality for the US population; the data are specific to age, sex, race, and calendar year and are derived from the National Center for Health Statistics (NCHS) of the Centers for Disease Control and Prevention $[23,28]$. Since NCHS does not provide subtype-specific breast cancer mortality data, we used overall breast cancer-specific mortality in place of breast cancer subtype-specific mortality and assumed that the difference in these mortality rates would be small at the population level. We limited our assessment to risks of developing a first breast cancer [23] and did not consider second primary breast cancer (a rare event affecting only $4 \%$ of breast cancer survivors) [29]. All analyses were conducted in accordance with the Institutional Review Board approval of the Cancer Prevention Institute of California (protocol number 2001-043).

\section{Results and Discussion}

\section{Study participants}

From the cohort of 40,936 women whose breast cancer was diagnosed in California in 2006-2007, we excluded 7,737 cases (18.9\%) having any of the three markers ER, PR, or HER2 coded as borderline, not tested, not recorded, or unknown. This excluded group comprised 5,069 whites, 505 blacks, 1,262 Hispanics, and 901 Asians; there were no significant differences according to race/ethnicity or age between the cases excluded for missing ER, PR, or HER2 results and the included cases that had ER, PR, and HER data available (results not shown). We included a total of 33,199 women, for whom data on ER, PR, and HER2 were available, in our analyses. Table 1 presents demographic and clinical 
Table 1 Characteristics of patients whose breast cancer was diagnosed in California from 2006 to 2007

\begin{tabular}{|c|c|c|c|c|c|c|c|}
\hline Race & $\begin{array}{c}\text { Breast cancers, } \\
\text { number } \\
\text { (percentage) }\end{array}$ & $\begin{array}{c}\text { Age in years, } \\
\text { number } \\
\text { (percentage) }\end{array}$ & $\begin{array}{c}\text { Stage, } \\
\text { number } \\
\text { (percentage) }\end{array}$ & $\begin{array}{l}\text { Size, number } \\
\text { (percentage) }\end{array}$ & $\begin{array}{c}\text { Luminal, } \\
\text { number } \\
\text { (percentage) }\end{array}$ & $\begin{array}{c}\text { HER2-positive, } \\
\text { number } \\
\text { (percentage) }\end{array}$ & $\begin{array}{c}\text { Triple-negative, } \\
\text { number } \\
\text { (percentage) }\end{array}$ \\
\hline \multirow[t]{5}{*}{ White } & $21,947(66.1)$ & $<40: 786$ (3.6) & $\begin{array}{c}\text { Local: } 14,161 \\
(64.5)\end{array}$ & $\begin{array}{c}\leq 2 \mathrm{~cm}: 13,537 \\
(61.7)\end{array}$ & $15,713(71.6)$ & $3,713(16.9)$ & $2,521(11.5)$ \\
\hline & & 40-49: 3,442 (15.7) & $\begin{array}{c}\text { Reg/Dist: 7,737 } \\
\text { (35.2) }\end{array}$ & $\begin{array}{c}>2 \mathrm{~cm}, \leq 5 \mathrm{~cm}: \\
6,386(29.1)\end{array}$ & & & \\
\hline & & 50-59: 5,335 (24.3) & $\begin{array}{c}\text { Unstaged: } 49 \\
(0.2)\end{array}$ & $\begin{array}{c}>5 \mathrm{~cm}: 1,475 \\
(6.7)\end{array}$ & & & \\
\hline & & 60-69: 5,468 (24.9) & & $\begin{array}{c}\text { Not available: } \\
549(2.5)\end{array}$ & & & \\
\hline & & $\geq 70: 6,916$ (31.5) & & & & & \\
\hline \multirow[t]{5}{*}{ Black } & $2,071(6.2)$ & <40: 137 (6.6) & $\begin{array}{l}\text { Local: } 1,128 \\
\quad(54.5)\end{array}$ & $\begin{array}{c}\leq 2 \mathrm{~cm}: 1,007 \\
(48.6)\end{array}$ & $1,098(53.0)$ & $464(22.4)$ & 509 (24.6) \\
\hline & & 40-49: 474 (22.9) & $\begin{array}{l}\text { Reg/Dist: } 931 \\
(45.0)\end{array}$ & $\begin{array}{c}>2 \mathrm{~cm}, \leq 5 \\
\mathrm{~cm}: 737(35.6)\end{array}$ & & & \\
\hline & & 50-59: 553 (26.7) & $\begin{array}{c}\text { Unstaged: } 12 \\
(0.6)\end{array}$ & $\begin{array}{c}>5 \mathrm{~cm}: 250 \\
(12.1)\end{array}$ & & & \\
\hline & & 60-69: 461 (22.3) & & $\begin{array}{c}\text { Not available: } \\
77 \text { (3.7) }\end{array}$ & & & \\
\hline & & $\geq 70: 446$ (21.5) & & & & & \\
\hline \multirow[t]{5}{*}{ Hispanic } & $5,523(16.6)$ & $<40: 582(10.5)$ & $\begin{array}{l}\text { Local: } 3,013 \\
\quad(54.6)\end{array}$ & $\begin{array}{c}\leq 2 \mathrm{~cm}: 2,788 \\
(50.5)\end{array}$ & $3,275(59.3)$ & $1,328(24.0)$ & $920(16.7)$ \\
\hline & & 40-49: 1,419 (25.7) & $\begin{array}{c}\text { Reg/Dist: 2,476 } \\
(44.8)\end{array}$ & $\begin{array}{c}>2 \mathrm{~cm}, \leq 5 \mathrm{~cm}: \\
1,993(36.1)\end{array}$ & & & \\
\hline & & 50-59: 1,414 (25.6) & $\begin{array}{c}\text { Unstaged: } 34 \\
(0.6)\end{array}$ & $\begin{array}{c}>5 \mathrm{~cm}: 562 \\
\quad(10.2)\end{array}$ & & & \\
\hline & & 60-69: 1,092 (19.8) & & $\begin{array}{c}\text { Not available: } \\
180 \text { (3.3) }\end{array}$ & & & \\
\hline & & $\geq 70: 1,016(18.4)$ & & & & & \\
\hline \multirow[t]{5}{*}{ Asian } & $3,658(11.0)$ & <40: 298 (8.1) & $\begin{array}{c}\text { Local: } 2,258 \\
\quad(61.7)\end{array}$ & $\begin{array}{c}\leq 2 \mathrm{~cm}: 2,069 \\
(56.6)\end{array}$ & $2,296(62.8)$ & $994(27.2)$ & $368(10.0)$ \\
\hline & & 40-49: $910(24.9)$ & $\begin{array}{c}\text { Reg/Dist: 1,385 } \\
\text { (37.9) }\end{array}$ & $\begin{array}{c}>2 \mathrm{~cm}, \leq 5 \mathrm{~cm}: \\
1,212(33.1)\end{array}$ & & & \\
\hline & & 50-59: 1,057 (28.9) & $\begin{array}{l}\text { Unstaged: } 15 \\
(0.4)\end{array}$ & $\begin{array}{c}>5 \mathrm{~cm}: 301 \\
\quad(8.2)\end{array}$ & & & \\
\hline & & 60-69: 712 (19.5) & & $\begin{array}{l}\text { Not available: } \\
76(2.1)\end{array}$ & & & \\
\hline & & 270: 681 (18.6) & & & & & \\
\hline \multirow[t]{4}{*}{$\begin{array}{l}\text { All } \\
\text { races }^{\mathrm{a}}\end{array}$} & $33,199(100)$ & $<40: 1,803$ (5.4) & $\begin{array}{c}\text { Local: } 20,560 \\
(61.9)\end{array}$ & $\begin{array}{c}\leq 2 \mathrm{cm:} 19,401 \\
(58.4)\end{array}$ & $22,382(67.4)$ & $6,499(19.6)$ & $4,318(13)$ \\
\hline & & 40-49: 6,245 (18.8) & $\begin{array}{c}\text { Reg/Dist: } \\
12,529 \text { (37.7) }\end{array}$ & $\begin{array}{c}>2 \mathrm{~cm}, \leq 5 \mathrm{~cm}: \\
10,328(31.1)\end{array}$ & & & \\
\hline & & 50-59: 8,359 (25.2) & $\begin{array}{c}\text { Unstaged: } 110 \\
(0.3)\end{array}$ & $\begin{array}{c}>5 \text { cm: } 2,588 \\
(7.8)\end{array}$ & & & \\
\hline & & 60-69: 7,733 (23.3) & & $\begin{array}{c}\text { Not available: } \\
882(2.7)\end{array}$ & & & \\
\hline
\end{tabular}

Data include age, race/ethnicity, stage (local, regional or distant [Reg/Dist], or unstaged), tumor size, and subtype: luminal (estrogen receptor [ER]- or progesterone receptor [PR]-positive or both and HER2/neu [HER2]-negative), HER2-positive (ER- and PR-positive or -negative and HER2-positive), and triplenegative (ER-negative, PR-negative, and HER2-negative). ${ }^{a}$ Excludes 7,737 cases (5,069 whites, 505 blacks, 1,262 Hispanics, and 901 Asians) for whom ER, PR, or HER2 were untested, borderline, missing, or unknown. 
characteristics of the patient population derived from the CCR. Among breast cancer cases, $66.1 \%$ were white, 6.2\% black, 16.6\% Hispanic, and 11\% Asian. Compared with other racial groups, white patients had a higher proportion of tumors that were luminal $(71.6 \%$ versus $53 \%$ to $62.8 \%)$, that were diagnosed in local stage (64.5\% versus $54.5 \%$ to $61.7 \%$ ), and that were diagnosed at a size of $2 \mathrm{~cm}$ or less (61.7\% versus $48.6 \%$ to $58.4 \%$ ). Black women had the highest proportion of tumors that were triple-negative (24.6\% versus $10 \%$ to $16.7 \%)$. A chisquare test of breast cancer subtypes by race yielded a $P$ value of less than 0.0001 , indicating a statistically significant difference in subtype distribution between racial groups.

\section{Lifetime risks by racial/ethnic group}

Table 2 presents absolute lifetime risks of developing specific breast cancer subtypes for white, black, Hispanic, and Asian women. All racial/ethnic groups have a higher lifetime risk of developing luminal breast cancer than any other subtype, but this luminal breast cancer risk varies significantly by race/ethnicity and ranges from $4.60 \%$ (95\% CI $4.40 \%$ to $4.81 \%$ ) for Hispanics to $8.10 \%$ (95\% CI 7.94\% to $8.20 \%$ ) for whites. Although the 95\% CIs around risks for HER2-positive breast cancer do not overlap between most racial/ethnic groups (for example, Hispanics $1.56 \%, 95 \%$ CI $1.46 \%$ to $1.68 \%$ and Asians $1.91 \%$, 95\% CI $1.78 \%$ to $2.07 \%$ ), the risk differences are smaller in magnitude than for the luminal subtype. For triple-negative breast cancer, blacks have the highest lifetime risk at $1.98 \%$ (95\% CI $1.80 \%$ to $2.17 \%$ ), which is significantly greater than that of Asian (0.77\%, 95\% CI $0.67 \%$ to $0.88 \%)$, Hispanic (1.04\%, 95\% CI $0.96 \%$ to $1.13 \%)$, and white $(1.25 \%, 95 \%$ CI $1.20 \%$ to $1.30 \%)$ women. For all races and all subtypes combined, overall absolute risk is $12.3 \%$ (95\% CI $12.2 \%$ to $12.4 \%$ ), which is consistent with 1 in 8 women developing breast cancer in her lifetime. Figure 1 presents race-specific incidence curves for each subtype.

\section{Absolute risks by age and racial/ethnic group}

Table 3 presents age-specific risks for breast cancer subtypes for women who are unaffected by cancer at age 40 . Between the ages of 40 and 49 , white women have $0.87 \%$ ( $95 \%$ CI $0.84 \%$ to $0.90 \%$ ) probability of developing luminal breast cancer, $0.27 \%$ (95\% CI $0.25 \%$ to $0.29 \%$ ) probability of developing HER2-positive breast cancer, and $0.17 \%$ ( $95 \%$ CI $0.16 \%$ to $0.19 \%$ ) probability of developing triple-negative breast cancer; for blacks, corresponding probabilities are $0.59 \%$ (95\% CI $0.52 \%$ to $0.66 \%$ ), $0.31 \%$ ( $95 \%$ CI $0.26 \%$ to $0.37 \%$ ), and $0.34 \%$ (95\% CI $0.29 \%$ to $0.40 \%)$. For all races, nearly half the lifetime probability of developing luminal breast cancer occurs after age 70, whereas triple-negative breast cancer and HER2-positive breast cancer subtypes have an earlier age distribution, as shown in Figure 2. The Supplemental table (Additional file 1) presents age-specific risks in 10-, 20-, and 30-year intervals in addition to lifetime risks for women ages 20 to 80 by race/ethnicity and by breast cancer subtype.

\section{Conclusions}

We present lifetime and age-specific probabilities of developing luminal (ER- or PR-positive or both and HER2negative), HER2-positive (ER- and PR-positive or -negative and HER2-positive), and triple-negative (ER-, PR-, and HER2-negative) subtypes of breast cancer for women from four racial/ethnic groups and use the most recently available data from the large and diverse population of California. These estimates refine the frequently cited 'one in eight' statistic [12], which fails to capture the substantial differences in epidemiology and prognosis among breast cancer subtypes [6-9,16,17]. Most importantly, these estimates facilitate clinically relevant discussion between patients and physicians. For women considering prevention strategies such as prophylactic tamoxifen or raloxifene, which reduce the incidence of only certain subtypes of breast cancer [30,31], or screening methods such as magnetic resonance imaging (MRI), which may contribute more to the detection of triple-negative than luminal

Table 2 Absolute lifetime risk $^{a}$ of developing breast cancer by subtype ${ }^{b}$ and race/ethnicityc

\begin{tabular}{lccccc}
\hline Breast cancer subtype & $\begin{array}{c}\text { White } \\
\text { Percentage (95\% Cl) }\end{array}$ & $\begin{array}{c}\text { Black } \\
\text { Percentage (95\% Cl) }\end{array}$ & $\begin{array}{c}\text { Hispanic } \\
\text { Percentage (95\% Cl) }\end{array}$ & $\begin{array}{c}\text { Asian } \\
\text { Percentage (95\% Cl) }\end{array}$ & $\begin{array}{c}\text { All races } \\
\text { Percentage (95\% Cl) }\end{array}$ \\
\hline Luminal $^{\text {b, d }}$ & $8.10(7.94,8.20)$ & $4.70(4.41,5.02)$ & $4.60(4.41,4.80)$ & $5.06(4.81,5.34)$ & $6.79(6.69,6.88)$ \\
HER2-positive $^{\text {b, d }}$ & $1.82(1.76,1.88)$ & $1.81(1.63,2.00)$ & $1.56(1.46,1.68)$ & $1.91(1.78,2.07)$ & $1.78(1.73,1.83)$ \\
Triple-negative $^{\text {b, d }}$ & $1.25(1.20,1.30)$ & $1.98(1.80,2.17)$ & $1.04(0.96,1.13)$ & $0.77(0.67,0.88)$ & $1.20(1.16,1.24)$ \\
Missing $_{\text {All subtypes }}$ & $2.68(2.60,2.76)$ & $2.32(2.11,2.56)$ & $1.81(1.68,1.95)$ & $2.23(2.04,2.44)$ & $2.44(2.38,2.50)$ \\
\hline
\end{tabular}

aLifetime risk is conditioned on never having had breast cancer previously. ${ }^{b}$ Subtypes were defined by expression of estrogen receptor (ER), progesterone receptor (PR), and Her2/neu (HER2) as follows: luminal (ER- or PR-positive or both and HER2-negative), HER2-positive (ER- and PR-positive or -negative and HER2positive), and triple-negative (ER-negative, PR-negative, and HER2-negative). 'Racial/ethnic categories are mutually exclusive and include white (non-Hispanic white), black (non-Hispanic black), Hispanic, and Asian (non-Hispanic Asian or Pacific Islander). dExcludes 7,737 cases (5,069 whites, 505 blacks, 1,262 Hispanics, and 901 Asians) for whom ER, PR, and/or HER2 were not tested or for whom results were borderline, missing, or unknown; these cases are included in the 'All subtypes' category. 'Includes 7,737 cases (5,069 whites, 505 blacks, 1,262 Hispanics, and 901 Asians) for whom ER, PR, and/or HER2 were not tested or for whom results were borderline, missing or unknown. $\mathrm{Cl}$, confidence interval. 
(a) Whites

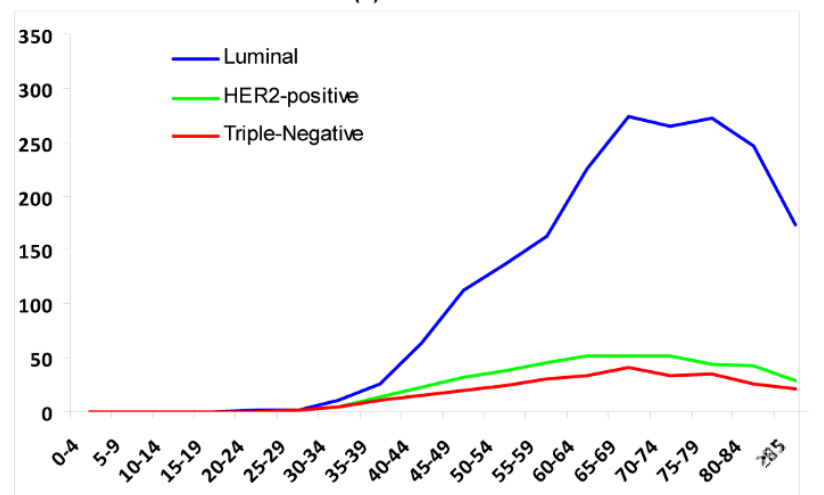

(c) Hispanics

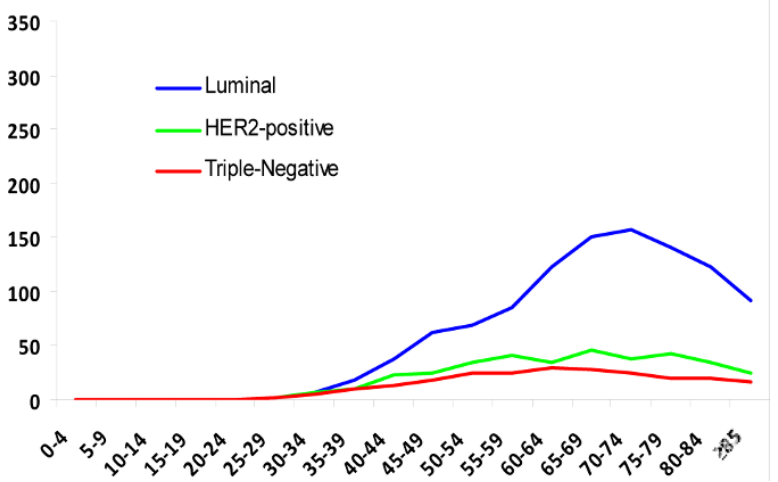

(b) Blacks

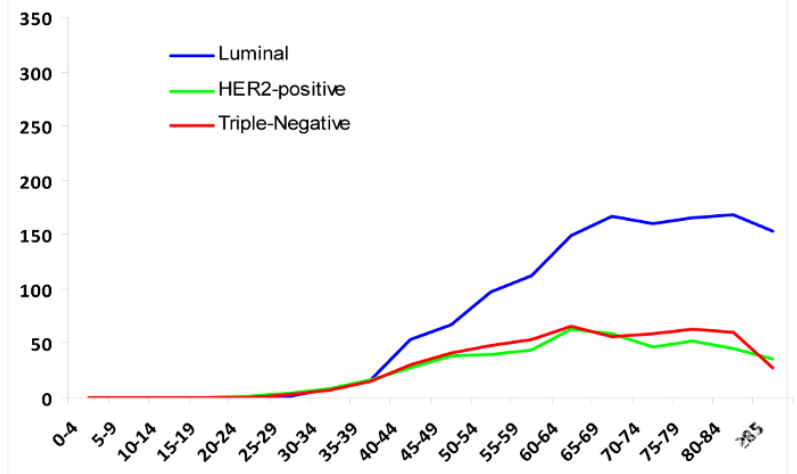

(d) Asians

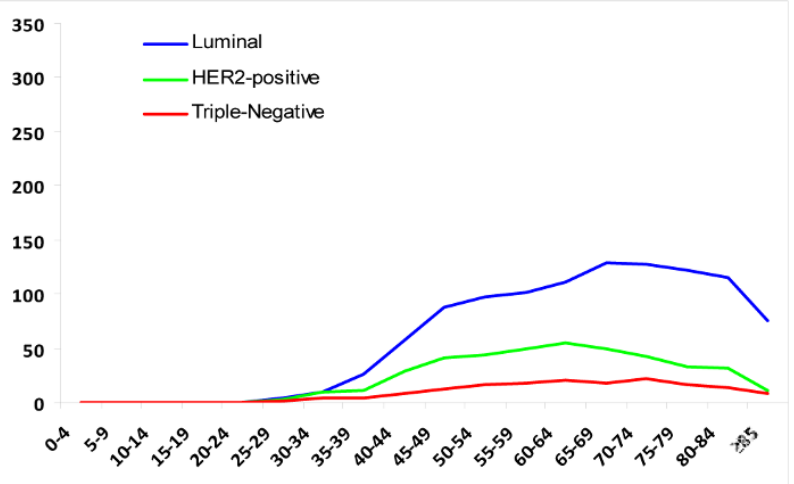

Figure 1 Age-specific incidence of breast cancer. Incidence is expressed as rates per 100,000 by age (in years) for subtypes - luminal (ER- or PR-positive or both and HER2-negative), HER2-positive (ER- and PR-positive or -negative and HER2-positive), and triple-negative (ER-negative, PRnegative, and HER2-negative) - and for racial/ethnic groups: (a) whites, (b) blacks, (c) Hispanics, and (d) Asians. ER, estrogen receptor; HER2,

Her2/neu; PR, progesterone receptor.

cancers $[9,10]$, our estimates may inform decisions about managing breast cancer risk. A woman at low risk for a specific subtype might choose to forego particular interventions and their side effects (for example, stroke and uterine cancer from tamoxifen or false-positive biopsies from screening mammogram or MRI) [30,32], depending on the relative importance of such side effects and her competing health risks.

We present statistics separately for women in four major racial/ethnic groupings because lifetime risks for breast cancer as a whole vary substantially by these groups. Most notable were the significantly increased risks of luminal breast cancer among whites and of triple-negative breast cancer among black women. Our findings are consistent with studies reporting greater relative risks of triple-negative breast cancer among black women $[5,7,8,33]$ and strengthen the rationale for investigating genetic, reproductive, and lifestyle factors that may mediate this racial difference, such as age at menarche, family cancer history, breastfeeding, and abdominal adiposity [34,35]. In all groups, the luminal subtype was the most common one. This universal predominance of luminal (ER- or PR-positive or both and HER2-negative) breast cancer, regardless of race, may be reassuring since this subtype has the best survival $[5,17]$, can be targeted by existing chemoprevention agents $[30,31]$, and may be most readily detectable by screening mammography $[9,10,36,37]$. Although the disproportionately increased risk among black women of poor-prognosis triple-negative breast cancer warrants further study and targeted interventions, black women may be reassured to learn that they also have a high probability of avoiding this disease over their lifetimes.

It is essential to differentiate risks according to a woman's current age. A prior analysis using SEER data characterized qualitative patterns of breast cancer incidence according to ER status and reported an age-related crossover between black and white women [38]. We found that, for all races and for all subtypes, absolute breast cancer risks were low between ages 40 and 49 years: less than $1 \%$ per subtype and less than $2 \%$ for all subtypes combined. For women between ages 50 and 59, risks of each subtype increased substantially, and the greatest increase was for luminal breast cancers in white women. Nearly 
Table 3 Absolute risk ${ }^{a}$ to develop breast cancer in specific age intervals for cancer-free 40-year-old women by subtype ${ }^{b}$ and race/ethnicityc

\begin{tabular}{|c|c|c|c|c|}
\hline Race/Ethnicity & $\begin{array}{c}\text { Luminal }^{b, d} \\
\text { Percentage }(95 \% \mathrm{Cl})\end{array}$ & 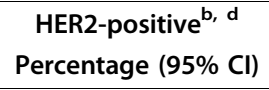 & $\begin{array}{c}\text { Triple-negative }{ }^{b, d} \\
\text { Percentage }(95 \% \mathrm{Cl})\end{array}$ & $\begin{array}{c}\text { All subtypes } \\
\text { Percentage }(95 \% \mathrm{Cl})\end{array}$ \\
\hline \multicolumn{5}{|l|}{ White, age 40} \\
\hline To age 50 & $0.87(0.84,0.90)$ & $0.27(0.25,0.29)$ & $0.17(0.16,0.19)$ & $1.57(1.52,1.61)$ \\
\hline To age 70 & $4.54(4.45,4.63)$ & $1.13(1.09,1.18)$ & $0.76(0.72,0.79)$ & $7.78(7.67,7.90)$ \\
\hline To end of life & $8.00(7.87,8.14)$ & $1.74(1.68,1.80)$ & $1.19(1.14,1.24)$ & $13.6(13.5,13.8)$ \\
\hline \multicolumn{5}{|l|}{ Black, age 40} \\
\hline To age 50 & $0.59(0.52,0.66)$ & $0.31(0.26,0.37)$ & $0.34(0.29,0.40)$ & $1.51(1.40,1.63)$ \\
\hline To age 70 & $2.83(2.63,3.03)$ & $1.19(1.07,1.33)$ & $1.31(1.18,1.45)$ & $6.49(6.02,6.80)$ \\
\hline To end of life & $4.55(4.35,4.76)$ & $1.73(1.55,1.92)$ & $1.91(1.73,2.11)$ & $10.7(10.3,11.2)$ \\
\hline \multicolumn{5}{|l|}{ Hispanic, age 40} \\
\hline To age 50 & $0.49(0.46,0.52)$ & $0.23(0.21,0.25)$ & $0.16(0.14,0.17)$ & $1.07(1.03,1.12)$ \\
\hline To age 70 & $2.49(2.38,2.59)$ & $0.94(0.88,1.01)$ & $0.65(0.60,0.71)$ & $4.99(4.85,5.14)$ \\
\hline To end of life & $4.79(4.59,5.00)$ & $1.50(1.39,1.61)$ & $0.98(0.90,1.07)$ & $8.83(8.56,9.11)$ \\
\hline \multicolumn{5}{|l|}{ Asian, age 40} \\
\hline To age 50 & $0.71(0.66,0.77)$ & $0.34(0.30,0.38)$ & $0.10(0.08,0.12)$ & $1.41(1.34,1.49)$ \\
\hline To age 70 & $2.81(2.68,2.95)$ & $1.28(1.19,1.37)$ & $0.45(0.40,0.51)$ & $5.67(5.47,5.87)$ \\
\hline To end of life & $4.92(4.66,5.20)$ & $1.70(1.66,1.97)$ & $0.72(0.63,0.84)$ & $9.68(9.31,10.1)$ \\
\hline \multicolumn{5}{|l|}{ All races, age 40} \\
\hline To age 50 & $0.72(0.70,0.74)$ & $0.27(0.26,0.28)$ & $0.17(0.16,0.18)$ & $1.41(1.38,1.44)$ \\
\hline To age 70 & $3.72(3.66,3.78)$ & $1.12(1.08,1.15)$ & $0.73(0.70,0.76)$ & $6.83(6.75,6.91)$ \\
\hline To end of life & $6.74(6.64,6.84)$ & $1.70(1.66,1.75)$ & $1.14(1.10,1.18)$ & $12.1(12.0,12.3)$ \\
\hline
\end{tabular}

${ }^{\mathrm{a}}$ Risk is conditioned on never having had breast cancer previously. ${ }^{\mathrm{b}}$ Subtypes were defined by expression of estrogen receptor (ER), progesterone receptor (PR), and Her2/neu (HER2): luminal (ER- or PR-positive or both and HER2-negative), HER2-positive (ER- and PR-positive or -negative and HER2-positive), and triplenegative (ER-negative, PR-negative, and HER2-negative). ' Racial/ethnic categories are mutually exclusive and include white (non-Hispanic [NH]), black (NH), Hispanic, and Asian (NH, includes Pacific Islander). ' Excludes 7,737 cases (5,069 whites, 505 blacks, 1,262 Hispanics, and 901 Asians) for whom ER, PR, and/or HER2 were not tested or for whom results were borderline, missing, or unknown; these cases are included in the 'All subtypes' category. Cl, confidence interval.

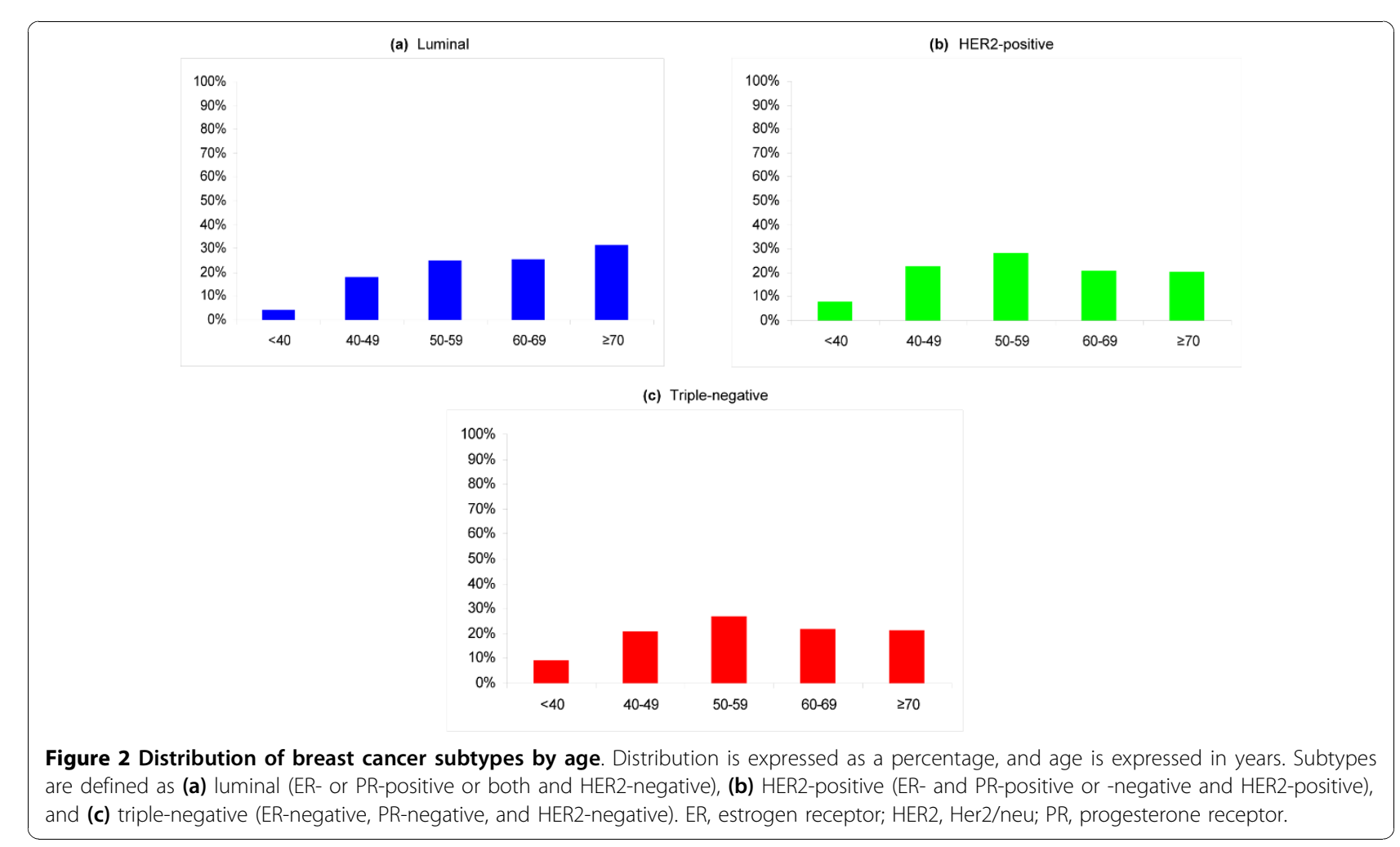


half the lifetime risk of luminal breast cancer, the dominant subtype for all racial/ethnic groups, occurred at or after age 70 . These findings are important to the ongoing critical examination of mammographic screening guidelines [32,36,39] and may warrant extending recommendations for mammographic screening beyond the current upper limit of 69 years of age [32].

Our analyses have certain limitations, which should be considered in interpreting our results. Given the DevCan program's competing-risks methodology, causespecific mortality is required to calculate incidence of the cancer in question [23,25]; we used overall US breast cancer mortality rates to calculate subtypespecific incidence [28] because subtype-specific mortality rates are not available. However, since overall breast cancer mortality is low at the population level, this is unlikely to affect our risk estimates substantially. Racial misclassification might present another potential source of bias, but given that prior studies of the CCR found that race data derive from patient self-report in more than $80 \%$ of cases [21], it seems improbable that a large proportion were incorrectly classified. We excluded 7,737 cases (18.9\%) from analysis because of missing ER, PR, or HER2 information; since there were no major differences in race or age distribution between the excluded and included cases, the lack of information on these cases seems unlikely to have biased our findings. Although defining subtypes by ER, PR, and HER2 expression does not entirely approximate results of genomic profiling, this classification offers a practical substitute that is increasingly well characterized in published literature [5,7-9,40-42] and that guides breast cancer treatment [43].

This study reports average lifetime risks at the population level; it does not address the urgent need for more accurate risk stratification of individual patients or the limitations of current breast cancer risk prediction models [44]. Genetic mutations such as BRCA1 convey dramatically increased risks of triple-negative breast cancer $[45,46]$, and the results of genome-wide association studies may eventually guide even more personalized risk prediction $[47,48]$. Our estimates may inform health policy and resource planning across diverse populations and may help patients and clinicians to weigh the average probabilities of developing specific breast cancer subtypes against other competing health risks.

\section{Additional material}

Additional File 1: Supplemental table. Absolute risk (\%) to develop breast cancer in specific age intervals, for cancer-free women by subtype and race/ethnicity.

\section{Abbreviations}

CCR: California Cancer Registry; Cl: confidence interval; ER: estrogen receptor; HER2: Her2/neu; IHC: immunohistochemistry; MRI: magnetic resonance imaging; NCHS: National Center for Health Statistics; NH: non-Hispanic; PR: progesterone receptor; SEER: Surveillance: Epidemiology and End Results.

\section{Acknowledgements}

This study was supported by the National Cancer Institute (NCl) Surveillance, Epidemiology and End Results (SEER) program under contract N01-PC-35136. The collection of cancer incidence data used in this study was supported by the California Department of Public Health as part of the statewide cancer reporting program mandated by California Health and Safety Code Section 103885; the NCI SEER program under contract N01-PC-35136 awarded to the Cancer Prevention Institute of California (formerly the Northern California Cancer Center), contract N01-PC-35139 awarded to the University of Southern California, and contract N01-PC-54404 awarded to the Public Health Institute; and the Centers for Disease Control and Prevention's National Program of Cancer Registries, under agreement 1U58DP00807-01 awarded to the Public Health Institute. The ideas and opinions expressed herein are those of the authors, and endorsement by the State of California, Department of Public Health, the $\mathrm{NCl}$, or the Centers for Disease Control and Prevention or their contractors and subcontractors is not intended nor should it be inferred.

\section{Author details}

${ }^{1}$ Department of Medicine, Stanford University School of Medicine, 259 Campus Drive, Stanford, CA 94305-5405, USA. ²Department of Health Research and Policy, Stanford University School of Medicine, 259 Campus Drive, Stanford, CA 94305-5405, USA. ${ }^{3}$ Cancer Prevention Institute of California, 2201 Walnut Avenue, Suite 300, Fremont, CA 94538, USA.

\section{Authors' contributions}

AWK conceived of the study, participated in study design and data interpretation, and drafted the manuscript. KF and SJS participated in study design and performed statistical analysis. CAC conceived of the study; participated in study design, analysis, and interpretation; and helped to draft the manuscript. All authors read and approved the final manuscript.

\section{Competing interests}

The authors declare that they have no competing interests.

Received: 31 August 2010 Revised: 9 November 2010

Accepted: 19 November 2010 Published: 19 November 2010

\section{References}

1. Fan $C$, Oh DS, Wessels $L$, Weigelt B, Nuyten DS, Nobel AB, van't Veer $L$, Perou CM: Concordance among gene-expression-based predictors for breast cancer. N Engl J Med 2006, 355:560-569.

2. Perou CM, Jeffrey SS, van de Rijn M, Rees CA, Eisen MB, Ross DT, Pergamenschikov A, Williams CF, Zhu SX, Lee JC, Lashkari D, Shalon D, Brown PO, Botstein D: Distinctive gene expression patterns in human mammary epithelial cells and breast cancers. Proc Natl Acad Sci USA 1999, 96:9212-9217.

3. Perou CM, Sorlie T, Eisen MB, van de Rijn M, Jeffrey SS, Rees CA, Pollack JR, Ross DT, Johnsen $H$, Akslen LA, Fluge O, Pergamenschikov A, Williams C, Zhu SX, Lonning PE, Borresen-Dale AL, Brown PO, Botstein D: Molecular portraits of human breast tumours. Nature 2000, 406:747-752.

4. Sorlie T, Tibshirani R, Parker J, Hastie T, Marron JS, Nobel A, Deng S, Johnsen H, Pesich R, Geisler S, Demeter J, Perou CM, Lonning PE, Brown PO, Borresen-Dale AL, Botstein D: Repeated observation of breast tumor subtypes in independent gene expression data sets. Proc Natl Acad Sci USA 2003, 100:8418-8423.

5. Carey LA, Perou CM, Livasy CA, Dressler LG, Cowan D, Conway K, Karaca G, Troester MA, Tse CK, Edmiston S, Deming SL, Geradts J, Cheang MC, Nielsen TO, Moorman PG, Earp HS, Millikan RC: Race, breast cancer subtypes, and survival in the Carolina Breast Cancer Study. JAMA 2006, 295:2492-2502.

6. Bauer KR, Brown M, Cress RD, Parise CA, Caggiano V: Descriptive analysis of estrogen receptor (ER)-negative, progesterone receptor (PR)negative, and HER2-negative invasive breast cancer, the so-called 
triple-negative phenotype: a population-based study from the California cancer Registry. Cancer 2007, 109:1721-1728.

7. Lund MJ, Trivers KF, Porter PL, Coates RJ, Leyland-Jones B, Brawley OW, Flagg EW, O'Regan RM, Gabram SG, Eley JW: Race and triple negative threats to breast cancer survival: a population-based study in Atlanta, GA. Breast Cancer Res Treat 2009, 113:357-370.

8. Stead LA, Lash TL, Sobieraj JE, Chi DD, Westrup JL, Charlot M, Blanchard RA, Lee JC, King TC, Rosenberg CL: Triple-negative breast cancers are increased in black women regardless of age or body mass index. Breast Cancer Res 2009, 11:R18.

9. Dent R, Trudeau M, Pritchard KI, Hanna WM, Kahn HK, Sawka CA, Lickley LA, Rawlinson E, Sun P, Narod SA: Triple-negative breast cancer: clinical features and patterns of recurrence. Clin Cancer Res 2007, 13:4429-4434.

10. Yang WT, Dryden M, Broglio K, Gilcrease M, Dawood S, Dempsey PJ, Valero V, Hortobagyi G, Atchley D, Arun B: Mammographic features of triple receptor-negative primary breast cancers in young premenopausal women. Breast Cancer Res Treat 2008, 111:405-410.

11. Li Cl, Daling JR, Porter PL, Tang MT, Malone KE: Relationship between potentially modifiable lifestyle factors and risk of second primary contralateral breast cancer among women diagnosed with estrogen receptor-positive invasive breast cancer. J Clin Oncol 2009, 27:5312-5318.

12. Li Cl, Mathes RW, Bluhm EC, Caan B, Cavanagh MF, Chlebowski RT, Michael Y, O'Sullivan MJ, Stefanick ML, Prentice R: Migraine history and breast cancer risk among postmenopausal women. J Clin Oncol 2010, 28:1005-1010

13. Ma H, Luo J, Press MF, Wang Y, Bernstein L, Ursin G: Is there a difference in the association between percent mammographic density and subtypes of breast cancer? Luminal A and triple-negative breast cancer. Cancer Epidemiol Biomarkers Prev 2009, 18:479-485.

14. Phipps Al, Malone KE, Porter PL, Daling JR, Li Cl: Reproductive and hormonal risk factors for postmenopausal luminal, HER-2overexpressing, and triple-negative breast cancer. Cancer 2008, 113:1521-1526.

15. Phipps Al, Malone KE, Porter PL, Daling JR, Li Cl: Body size and risk of luminal, HER2-overexpressing, and triple-negative breast cancer in postmenopausal women. Cancer Epidemiol Biomarkers Prev 2008, 17:2078-2086

16. Carey LA, Dees EC, Sawyer L, Gatti L, Moore DT, Collichio F, Ollila DW, Sartor Cl, Graham ML, Perou CM: The triple negative paradox: primary tumor chemosensitivity of breast cancer subtypes. Clin Cancer Res 2007, 13:2329-2334.

17. Parise CA, Bauer KR, Brown MM, Caggiano V: Breast cancer subtypes as defined by the estrogen receptor (ER), progesterone receptor (PR), and the human epidermal growth factor receptor 2 (HER2) among women with invasive breast cancer in California, 1999-2004. Breast J 2009, 15:593-602.

18. Liedtke C, Mazouni C, Hess KR, Andre F, Tordai A, Mejia JA, Symmans WF, Gonzalez-Angulo AM, Hennessy B, Green M, Cristofanilli M, Hortobagyi GN Pusztai L: Response to neoadjuvant therapy and long-term survival in patients with triple-negative breast cancer. J Clin Oncol 2008, 26:1275-1281.

19. Surveillance, Epidemiology and End Results. [http://seer.cancer.gov/]

20. California Cancer Reporting System Standards. In Cancer Reporting in California, System Standards: Abstracting and Coding Procedures for Hospitals. Volume 1.. 8 edition. Sacramento, CA: California Cancer Registry, Data Standards and Quality Control Unit; 2008.

21. Gomez SL, Le GM, West DW, Satariano WA, O'Connor L: Hospital policy and practice regarding the collection of data on race, ethnicity, and birthplace. Am J Public Health 2003, 93:1685-1688.

22. Huober J, von Minckwitz G, Denkert C, Tesch H, Weiss E, Zahm DM, Belau A, Khandan F, Hauschild M, Thomssen C, Hogel B, Darb-Esfahani S, Mehta K, Loibl S: Effect of neoadjuvant anthracycline-taxane-based chemotherapy in different biological breast cancer phenotypes: overall results from the GeparTrio study. Breast Cancer Res Treat 2010, 124:133-140.

23. DevCan - Probability of Developing or Dying of Cancer. [http://srab. cancer.gov/devcan/].

24. Fay MP: Estimating age conditional probability of developing disease from surveillance data. Popul Health Metr 2004, 2:6.

25. Fay MP, Pfeiffer R, Cronin KA, Le C, Feuer EJ: Age-conditional probabilities of developing cancer. Stat Med 2003, 22:1837-1848.
26. Feuer EJ, Wun LM, Boring CC, Flanders WD, Timmel MJ, Tong T: The lifetime risk of developing breast cancer. J Natl Cancer Inst 1993, 85:892-897.

27. Wun LM, Merrill RM, Feuer EJ: Estimating lifetime and age-conditional probabilities of developing cancer. Lifetime Data Anal 1998, 4:169-186.

28. National Center for Health Statistics homepage. [http://www.cdc.gov/ nchs/index.htm]

29. Bernstein JL, Lapinski RH, Thakore SS, Doucette JT, Thompson WD: The descriptive epidemiology of second primary breast cancer. Epidemiology 2003, 14:552-558.

30. Fisher B, Costantino JP, Wickerham DL, Cecchini RS, Cronin WM, Robidoux A, Bevers TB, Kavanah MT, Atkins JN, Margolese RG, Runowicz CD, James JM, Ford LG, Wolmark N: Tamoxifen for the prevention of breast cancer: current status of the National Surgical Adjuvant Breast and Bowel Project P-1 study. J Natl Cancer Inst 2005, 97:1652-1662.

31. Vogel VG, Costantino JP, Wickerham DL, Cronin WM, Cecchini RS, Atkins JN, Bevers TB, Fehrenbacher L, Pajon ER Jr, Wade JL, Robidoux A, Margolese RG, James J, Lippman SM, Runowicz CD, Ganz PA, Reis SE, McCaskill-Stevens W, Ford $L G$, Jordan VC, Wolmark N: Effects of tamoxifen vs raloxifene on the risk of developing invasive breast cancer and other disease outcomes: the NSABP Study of Tamoxifen and Raloxifene (STAR) P-2 trial. JAMA 2006, 295:2727-2741.

32. Nelson HD, Tyne K, Naik A, Bougatsos C, Chan BK, Humphrey L: Screening for breast cancer: an update for the U.S. Preventive Services Task Force. Ann Intern Med 2009, 151:727-737, W237-742.

33. Huo D, Ikpatt F, Khramtsov A, Dangou JM, Nanda R, Dignam J, Zhang B, Grushko T, Zhang C, Oluwasola O, Malaka D, Malami S, Odetunde A, Adeoye AO, lyare F, Falusi A, Perou CM, Olopade Ol: Population differences in breast cancer: survey in indigenous African women reveals over-representation of triple-negative breast cancer. $J$ Clin Oncol 2009, 27:4515-4521.

34. Millikan RC, Newman B, Tse CK, Moorman PG, Conway K, Dressler LG, Smith LV, Labbok MH, Geradts J, Bensen JT, Jackson S, Nyante S, Livasy C, Carey L, Earp HS, Perou CM: Epidemiology of basal-like breast cancer. Breast Cancer Res Treat 2008, 109:123-139.

35. Yang XR, Sherman ME, Rimm DL, Lissowska J, Brinton LA, Peplonska B, Hewitt SM, Anderson WF, Szeszenia-Dabrowska N, Bardin-Mikolajczak A, Zatonski W, Cartun R, Mandich D, Rymkiewicz G, Ligaj M, Lukaszek S, Kordek R, Garcia-Closas M: Differences in risk factors for breast cancer molecular subtypes in a population-based study. Cancer Epidemiol Biomarkers Prev 2007, 16:439-443.

36. Esserman $L$, Shieh $Y$, Thompson I: Rethinking screening for breast cancer and prostate cancer. JAMA 2009, 302:1685-1692.

37. Ikeda DM, Andersson I, Wattsgard C, Janzon L, Linell F: Interval carcinomas in the Malmo Mammographic Screening Trial: radiographic appearance and prognostic considerations. AJR Am J Roentgenol 1992, 159:287-294.

38. Anderson WF, Rosenberg PS, Menashe I, Mitani A, Pfeiffer RM: Age-related crossover in breast cancer incidence rates between black and white ethnic groups. J Natl Cancer Inst 2008, 100:1804-1814.

39. Partridge $A H$, Winer EP: On mammography-more agreement than disagreement. N Engl J Med 2009, 361:2499-2501.

40. Dawood S, Broglio K, Kau SW, Green MC, Giordano SH, Meric-Bernstam F, Buchholz TA, Albarracin C, Yang WT, Hennessy BT, Hortobagyi GN, Gonzalez-Angulo AM: Triple receptor-negative breast cancer: the effect of race on response to primary systemic treatment and survival outcomes. J Clin Oncol 2009, 27:220-226

41. Tan DS, Marchio C, Jones RL, Savage K, Smith IE, Dowsett M, Reis-Filho JS: Triple negative breast cancer: molecular profiling and prognostic impact in adjuvant anthracycline-treated patients. Breast Cancer Res Treat 2008, 111:27-44.

42. Blows FM, Driver KE, Schmidt MK, Broeks A, van Leeuwen FE, Wesseling J, Cheang MC, Gelmon K, Nielsen TO, Blomqvist C, Heikkila P, Heikkinen T, Nevanlinna $H$, Akslen LA, Begin LR, Foulkes WD, Couch FJ, Wang X, Cafourek V, Olson JE, Baglietto L, Giles GG, Severi G, McLean CA, Southey MC, Rakha E, Green AR, Ellis IO, Sherman ME, Lissowska J, et al: Subtyping of breast cancer by immunohistochemistry to investigate a relationship between subtype and short and long term survival: a collaborative analysis of data for 10,159 cases from 12 studies. PLoS Med 2010, 7:e1000279.

43. Carlson RW, Allred DC, Anderson BO, Burstein HJ, Carter WB, Edge SB, Erban JK, Farrar WB, Goldstein LJ, Gradishar WJ, Hayes DF, Hudis CA, 
Jahanzeb M, Kiel K, Ljung BM, Marcom PK, Mayer IA, McCormick B,

Nabell LM, Pierce L, Reed EC, Smith ML, Somlo G, Theriault RL, Topham NS,

Ward JH, Winer EP, Wolff AC: Breast cancer. Clinical practice guidelines in oncology. J Natl Compr Canc Netw 2009, 7:122-192.

44. Amir E, Freedman OC, Seruga B, Evans DG: Assessing women at high risk of breast cancer: a review of risk assessment models. J Natl Cancer Inst 2010, 102:680-691.

45. Atchley DP, Albarracin CT, Lopez A, Valero V, Amos Cl, GonzalezAngulo AM, Hortobagyi GN, Arun BK: Clinical and pathologic characteristics of patients with BRCA-positive and BRCA-negative breast cancer. J Clin Oncol 2008, 26:4282-4288.

46. Chen S, Parmigiani G: Meta-analysis of BRCA1 and BRCA2 penetrance. $J$ Clin Oncol 2007, 25:1329-1333.

47. Reeves GK, Travis RC, Green J, Bull D, Tipper S, Baker K, Beral V, Peto R, Bell J, Zelenika D, Lathrop M: Incidence of breast cancer and its subtypes in relation to individual and multiple low-penetrance genetic susceptibility loci. JAMA 2010, 304:426-434.

48. Wacholder S, Hartge P, Prentice R, Garcia-Closas M, Feigelson HS, Diver WR, Thun MJ, Cox DG, Hankinson SE, Kraft P, Rosner B, Berg CD, Brinton LA, Lissowska J, Sherman ME, Chlebowski R, Kooperberg C, Jackson RD, Buckman DW, Hui P, Pfeiffer R, Jacobs KB, Thomas GD, Hoover RN, Gail MH, Chanock SJ, Hunter DJ: Performance of common genetic variants in breast-cancer risk models. N Engl J Med 2010, 362:986-993.

doi:10.1186/bcr2780

Cite this article as: Kurian et al: Lifetime risks of specific breast cancer subtypes among women in four racial/ethnic groups. Breast Cancer Research 2010 12:R99.

\section{Submit your next manuscript to BioMed Central} and take full advantage of:

- Convenient online submission

- Thorough peer review

- No space constraints or color figure charges

- Immediate publication on acceptance

- Inclusion in PubMed, CAS, Scopus and Google Scholar

- Research which is freely available for redistribution

Submit your manuscript at www.biomedcentral.com/submit 